\title{
ISOLATED METACHRONIC METASTATIC CLEAR CELL RENAL CELL CARCINOMA IN THE THYROID GLAND 7 YEARS AFTER NEPHRECTOMY
}

\author{
Waniczek D. ${ }^{1}$, Kamiński T. ${ }^{2}$, Augustyniak H. ${ }^{3}$, Nadbrzeżna D. ${ }^{1}$, Czarniecka A. ${ }^{4}$ \\ ${ }^{1}$ Medical University of Silesia, Chair and Departament of General and Gastrointestinal Surgery, Bytom, Poland \\ ${ }^{2}$ University of Physical Education in Katowice, Poland \\ ${ }^{3}$ Independent Public Health Care Hospital in Katowice, Urology Department, Katowice, Poland \\ ${ }^{4}$ Maria Skłodowska-Curie Memorial Cancer Center and Institute of Oncology, Gliwice Branch, Surgery \\ Department, Poland
}

\section{A bstract}

Thyroid gland is a rare site for distant metastases. The aim of this study is to present a rare case of an isolated metastatic clear cell renal cell cancer (ccRCC) in the thyroid gland seven years after left-sided nephrectomy.

A neck cancer discovered by clinical examination, diagnosed by ultrasound-guided USG fine-needle biopsy was removed by surgery. Palliative thyroidectomy with consecutive neck radiotherapy was finished without any complications, except a temporary, asymptomatic hypocalcaemia. After six month remission, the patient's general condition deteriorated, multiorgan RCC dissection appeared leading to the patient's death.

Key words: renal carcinoma, thyroid metastases, fine-needle biopsy

\section{INTRODUCTION}

Thyroid gland is one of the largest endocrine glands as well as one of the organs with the best blood supply with the blood flow of c. $8 \mathrm{ml} / 100 \mathrm{~g}$ tissue/s. Despite of a profuse perfusion, it is a rare site of distant metastases. The most common source of thyroid metastases is renal cell carcinoma ( $\mathrm{RCC}$ ) in advanced, disseminated stage. Therefore, a renal cell carcinoma with multiorgan dissection, preceded by metachronic isolated thyroid metastasis is a very special case.

The aim of the study is to present a rare case of the isolated ccRCC metastasis in the thyroid gland 7 years after a left-sided nephrectomy.

\section{Case report}

72-year patient A.U., after left-sided nephrectomy due to clear cell renal cell carcinoma reported to the surgery clinic because of the neck tumour detected by palpation. The tumour appeared several months before and was increasing gradually. Left-sided nephrectomy was done in 2001, kidney with the adrenal gland were removed; the histopathology test of the $6 \mathrm{~cm}$ tumour was clear cell renal cell cancer (ccRCC); pT1bNOM0, graiding G2 according to Fuhrman. Neck tumour did not cause any disorders. The results of the initial laboratory tests, including blood morphology, electrolytes, hepatic, and renal tests, thyroid activity tests were within the norm. The results of cytology after fine-needle biopsy (FNB) of the largest nodule left lobe of the thyroid, diameter $1.6 \times 1.0 \mathrm{~cm}$, showed a presence of atypical, malignant cells suspected of being ccRCC (Fig.1). Neck computed tomography (CT) showed a retrosternal goitre relocating the trachea to the right side. Lower pole of the left lobe of the thyroid reached below the upper sternum edge. Chest CT - no heterogeneous structures were found. Abdominal and pelvic computed tomography showed a condition

Address for correspondence:

dr n.med. Dariusz Waniczek, Szpital Specjalistyczny nr 1, Katedra i Oddział Kliniczny chirurgii Ogólnej i Gastroenterologicznej, ul. Żeromskiego, 741-902 Bytom, Poland

Phone: +48 501252 191; fax: +48 322819464 ; e-mail: dariusz.waniczek@gmail.com 
after left-sided nephrectomy - intestinal loops visible in the site of the kidney removal, no local tumour recurrence or metastasis to other organs.

The patient was qualified for the total thyroidectomy. The thyroid was removed palliatively with the central lymphatic system and a fragment of the internal cervical vein covered with the infiltration from the thyroid. The direct biopsy of lateral cervical lymph nodes on the left side did not show metastases. Postoperative histopathology test - ccRCC metastaticum multicentricum in struma nodosa (Fig.2). Numerous metastatic nodules occupying both gland parenchyma and growing outside the thyroid fibrous capsule. Nodules were like unconnected, autonomous metastases. Inner vein lumen and wall were free from neoplasm proliferation. 11 lymph nodes with metastases were found in the central lymphatic system in 16 lymph nodes that had been removed. In 9 cases the neoplasm infiltration went outside a gland capsule.

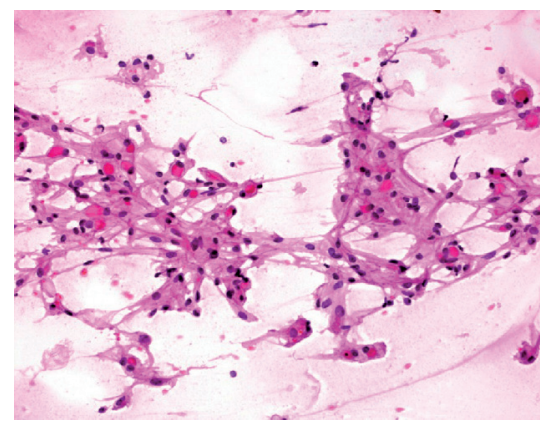

Fig. 1 Cytology from fine-needle biopsy of ccRCC

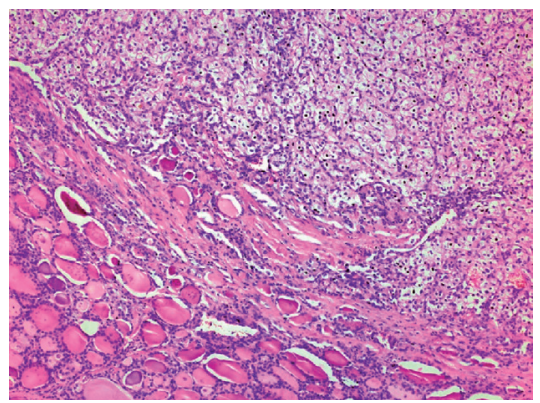

Fig.2 Metastatic clear cell renal cell carcinoma in the thyroid gland 
Postoperative period was without complications except temporal symptomless hypocalcemia. After one month, two week radiotherapy was performed in the outpatient clinic. Next, a systemic therapy with sunitynib was proposed. The patient rejected the proposition of this treatment. The patient survived another 6 months in a good condition. After that, her general condition deteriorated quickly, body lost weight. Image examinations showed liver and lung metastases. No cervical metastases were found. The patient died after another 2 months.

\section{DISCUSSION}

The most common source of thyroid metastases are kidney, lung, chest, oesophagus, colon and throat cancers. Although thyroid has a very good vascular supply, the occurrence of metastases in this organ is quite rare. It probably is a result of difficulties that neoplastic cells have to settle due to a fast blood flow, another reason could be a specific gland tissue environment rich in oxygen and iodine (1).

$\mathrm{RCC}$ has a specific tendency to create metastases through blood. Sometime, it has atypical clinical course; distant metastases through blood to inner organs, including thyroid, with no local lesions which could be detected by the available methods or with metastases occurring many years after primary tumour removal. Additionally, metastases accompanying RCC dissection can also occur. In our case, a cervical tumour discovered accidentally in a 72-year old patient appeared to be a clinically isolated renal metastasis 7 years after a nephrectomy.

Symptoms of neoplastic metastases into thyroid are nonspecific - they include cervical tumour, body mass loss, hypercalcaemia, swallowing disorders or hoarseness. However, the course of the disease is most often symptomless $(2,3)$. Although, thyroid gland is a rare site of distant metastases, very difficult to diagnose clinically, the more and more common FNB increased a number of diagnoses of non-thyroid cancers metastases. In the differential diagnosis we use imaging examinations such as scintigraphy, CT and USG with FNB. However, their effectiveness is unsatisfactory. All these methods are often unable to put a proper diagnosis. Although FNB may also false suggest a primary follicular tumour of thyroid, however, is an important element in the diagnosis of metastatic thyroid tumours. Sometimes the indications for surgery are ultimately clinically alarming symptoms such as: a single nodule, rapidly expanding, with a hard texture and uneven surface.

Before, RCC metastases into thyroid were diagnosed most often during autopsy or after thyroid surgeries $(1,3,4,5)$.

The patient's clinical examination was accompanied by USG and FNB. These examinations are used for diagnosing thyroid tumours and they are also a method of qualification for surgeries. Chen et al. (6) claim that per 10 thyroid metastatic tumours, 5 were RCC metastases. However, most lesions appeared 3 years after the primary lesion removal, one metastasis appeared only after 19 years. Dequanter et al. (7) found out that among 11 discovered and resectioned isolated metastases to thyroid, 5 were pulmonary squamous cell carcinoma metastases, 2 RCC metastases. These lesions appeared on average 25 months after primary tumour resection, survival median was 10 months. Cichon et al. (8) discovered 11 RCC out of 17 removed thyroid metastatic lesions.Similarly, Calzolari et al. (9) found 15 cases originating from RCC out of 25 non-thyroid cancer metastases.

It seems that despite bad prognosis in cases of distant RCC metastasis to thyroid, palliative surgery should be undertaken. Some authors observed positive influence of palliative surgery on survival $(2,6,7,9,10,11)$. Iesalnieks et al. (12) in their retrospective study, analysing 45 cases of RCC metastases to thyroid showed that 5-year survival in those patients was $51 \%$, and a prognosis got worse with the patient's age. All the authors underline no relapse in cervical area if the operation was possible within histologically unchanged margin. 
The neoplasm dissection was acknowledged to be the main reason of death $(6,7,8,9,11,12)$. Our patient felt very well 6 months after the operation and palliative radiotherapy. However, after this time her condition deteriorated and numerous metastases to lungs and liver were found. Still, neck CT did not show local disease relapse. After death no autopsy was done, disseminated ccRCC dissection was assumed to be the reason of death. In the clinical course of clear cell renal cell carcinoma, apart from the risk of local relapse, there is a great risk of dissection. Most authors agree that an appearance of isolated metastases of this cancer is an indication for surgical treatment. It refers not only to thyroid but also metastases to liver, lungs or brain.

This kind of treatment was applied in our patient, the surgery was accompanied by radiotherapy, which resulted in full local remission but did not prevent dissection. Classic systemic therapy is not effective in preventing dissection or inhibiting progression. Presently, drugs with molecular targets are used more often. Limitations of the therapy include general patient's condition, tolerating side-effects and finally, patient's consent. The suggested sunitynib (Sutent) is applied in the first treatment line in patients of favourable and intermediary prognosis $(11,13)$.

\section{REFERENCES}

1. Kim AY, Sung BP, Hee SC, Jae CH. Isolated Thyroid Metastasis From Renal Cell Carcinoma. Journal of ultrasound in medicine 2007;26,12:1799-1802.

2. Takashima S, Takayama F, Wang JC, Saito A, Kawakami S, Kobayashi S, Sone S. Radiologic assessment of metastases to the thyroid gland. J Comput Assist Tomogr 2000; 24:539-545.

3. Kim TY, Kim WB, Gong G, Hong SJ, Shong YK. Metastasis to the thyroid diagnosed by fine-needle aspiration biopsy Clin Endocrinol (Oxf). 2005 Feb;62(2):236-41.

4. Court-Payen M, Nygaard B, Hom T, Jacobsen O, Brændstrup O, Narvestad E, Pedersen M, Hancke S, Holm H. US-guided fine-needle aspiration biopsy of thyroid nodules. Acta Radiol 2002; 43:131-140.

5. Screaton NJ, Berman LH, Grant JW. US-guided core-needle biopsy of the thyroid gland. Radiology 2003; 226:827-832.

6. Chen H, Nicol TL, Udelsman R. Clinically significant, isolated metastatic disease to the thyroid gland. World $\mathrm{J}$ Surg 1999;23(2): 177-80.

7. Dequanter D, Lothaire P, Larsimont D, de Saint-Aubain de Somerhausen N, Andry G. Intrathyroid metastasis: 11 cases. Ann Endocrinol 2004;65(3):205-8.

8. Cichoń S, Anielski R, Konturek A, Barczyński M, Cichoń W. Metastases to the thyroid gland: seventeen cases operated on in a single clinical center. Langenbecks Arch Surg 2006;391(6):581-7.

9. Calzolari F, Sartori PV, Talarico C, Parmeggiani D, Beretta E, Pezzullo L, Bovo G, Sperlongano P, Monacelli M, Lucchini R, Misso C, Gurrado A, D’Ajello M, Uggeri F, Puxeddu E, Nasi P, Testini M, Rosato L, Barbarisio A, Avenia N. Surgical treatment of intrathyroid metastases: preliminary results of a multicentric study. Anticancer Res 2008;28(5B):2885-8.

10. Menegaux F, Chigot JP. Thyroid metastasis. Ann Chir 2001; 126:981-984.

11. Ljungberg B, Cowan NC, Hanbury DC, Hora M, Kuczyk MA, Merseburger AS, Patard JJ, Mulders PF, Sinescu IC. EAU guidelines on renal cell carcinoma: the 2010 update. Eur Urol. 2010;58(3):398-406.

12. Iesalnieks I, Winter H, Bareck E, Sotiropoulos GC, Goretzki PE, Klinkhammer-Schalke M, Bröckner S, Trupka A, Anthuber M, Rupprecht H, Raab M, Meyer W, Reichmann F, Kästel M, Mayr M, Braun W, Schlitt HJ, Agha A. Thyroid metastases of renal cell carcinoma: clinical course in 45 patients undergoing surgery. Assessment of factors affecting patients' survival. Thyroid 2008;18(6):615-24.

13. Motzer RJ, Hutson TE, Tomczak P, Michaelson MD, Bukowski RM, Oudard S, Negrier S, Szczylik C, Pili R, Bjarnason GA, Garcia-del-Muro X, Sosman JA, Solska E, Wilding G, Thompson JA, Kim ST, Chen I, Huang X, Figlin RA. Overall survival and updated results for sunitinib compared with interferon alfa in patients with metastatic renal cell carcinoma. J Clin Oncol. 2009;27(22):3584-90.

Received: Sept. 26, 2012

Accepted: Dec. 10, 2012 